\title{
Evaluation of Composite Cephalometric Norms in South Indian Subjects
}

\author{
Dr Lalitha Chiurupati,' Dr Anupriya Jaitly,2 Dr Vasumurthy Sesham,3 Dr Sri Harsha Yelchuru4 \\ 'Reader, ${ }^{4}$ Assistant Professor, Dept of Orthodontics, CKS Theja Institute of Dental Sciences, Tirupathi \\ ${ }^{2}$ Assistant Professor, Dept of Orthodontics, Sri Sai College of Dental Sciences, Vikarabad \\ ${ }^{3}$ Professor, Dept of Orthodontics, Kamineni Institute of Dental Sciences, Narketpally, India
}

\section{ABSTRACT}

Introduction: Cephalometrics is an important diagnostic tool in formulating comprehensive treatment planning in orthodontics. Different norms for different ethnic groups are essential to achieve accurate treatment results.

Objective: The present study aims in standardizing norms for composite cephalometric analysis in South Indian subjects.

Materials \& Method: A sample size of 40 subjects included 20 males and 20 females of age ranging between 18-30 years represented South Indian sample. Patients' cephalogram was taken in the natural head position. Individual norms from various cephalometric analyses were taken and synthesized into a composite analysis based on the idea of diagnostic block were evaluated.

Results: Parameters like upper incisor to NA, lower incisor to NB, interincisal angle, IMPA and upper incisor to SN suggested increased values indicating proclination of anterior teeth and mild convexity of soft tissues to be esthetically acceptable in South Indian subjects.

Conclusion: Different set of cephalometric norms for different ethnic groups should be formulated so as to guide the orthodontist and surgeon to optimize the treatment plan based on local norms.

Keywords: Composite analysis, natural head position, treatment planning

\section{INTRODUCTION}

Cephalometry means "head measuring" and cephalometric analysis is the study of dental and skeletal relationships to the head. With the cephalometric film, we can make absolute measurements, both linear and angular. The control over three factors in cephalometrics; patient's position, film, and the position of $x$-ray tube render important difference from conventional x-ray techniques.' Cephalometric norms provide guidelines to clinicians during diagnosis and treatment planning. Orthodontic treatment has shown improved outcome in cases where facial and cephalometric characteristics of ethnic background of the patient was considered while planning the treatment. ${ }^{2,3}$ However, many clinicians and researchers rely on the same 'Caucasian norms' to the people with different genetic origin. It has been recognized over the years that clinically significant variations in the craniofacial morphology and soft tissues are found among various ethnic groups. ${ }^{3.4}$ This justifies the need to study and develop cephalometric norms for population with unique facial morphology.
Hence, the purpose of this study was to establish the composite cephalometric norms for South Indian subjects; which includes the natives of Tamil Nadu, Kerala, Karnataka and Andhra Pradesh of India.

\section{MATERIALS AND METHOD}

The present study included a randomly collected sample of 40 subjects including 20 males and 20 females of the age ranging between 18-30 years of South Indian subjects. The inclusion criteria for the subjects were: Class I molar and canine relationship, straight facial profile, no previous history of orthodontic and prosthodontic treatment, no crowding, no rotations, spacing less than $2 \mathrm{~mm}$, and well aligned arches.

The lateral cephalogram of each patient was taken in natural head position as described by Viazis. ${ }^{5}$ Anatomical landmarks are illustrated in Figure 1 and Figure 2 and the parameters measured are given in Table 1. Cephalometric measurements were done and mean and standard deviation for each parameter was statistically determined. 


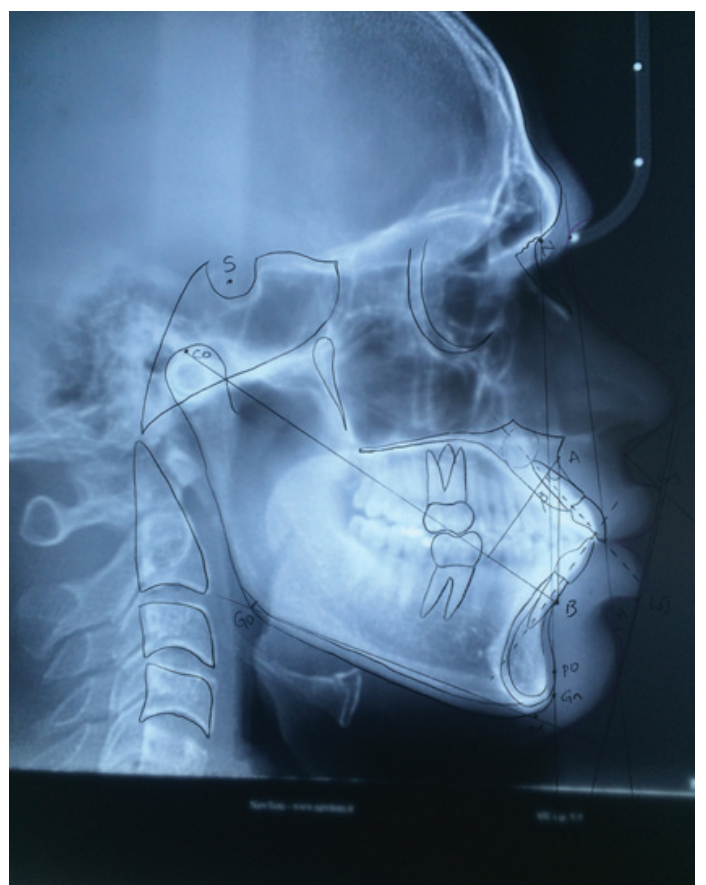

Figure 1: Patient cephalogram

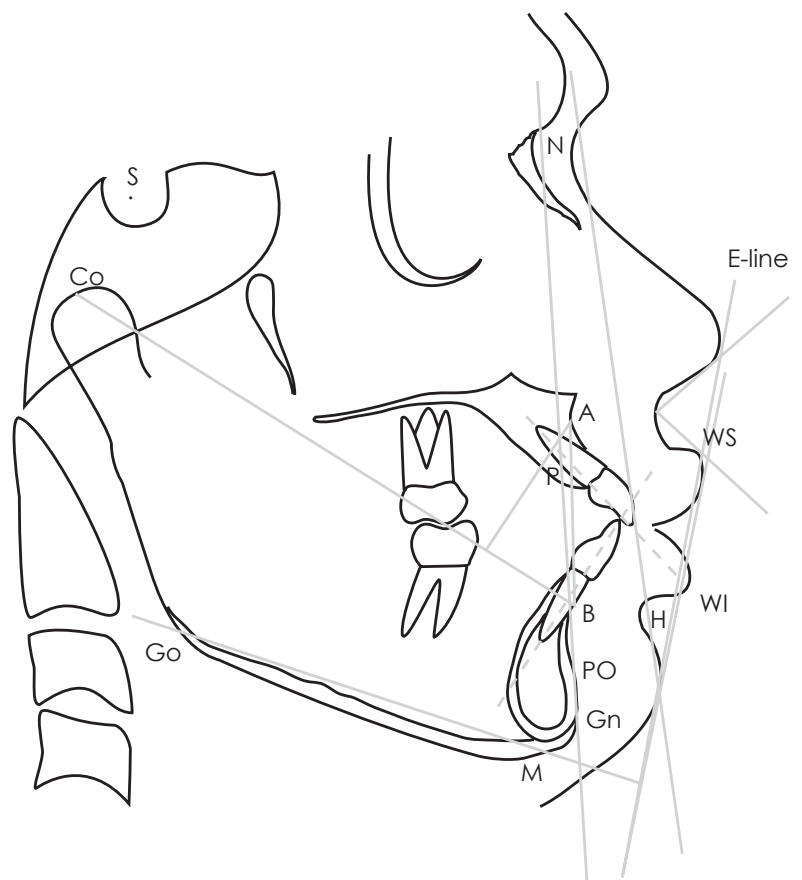

Figure 2: Landmarks on lateral cephalogram

Table 1: Composite cephalometric parameters of South Indian subjects

\begin{tabular}{|c|c|c|c|c|c|}
\hline \multirow{2}{*}{ S.No } & \multirow{2}{*}{ Parameter } & \multicolumn{2}{|c|}{ Standard } & \multicolumn{2}{|c|}{ South Indian Norms } \\
\hline & & Value & Analysis & Male & Female \\
\hline 1 & SNA & $82^{\circ}$ & Steiner ${ }^{6}$ & $82.1 \pm 1.55^{\circ}$ & $82.6 \pm 1.24^{\circ}$ \\
\hline 2 & SNB & $80^{\circ}$ & Steiner ${ }^{6}$ & $79.4 \pm 1.14^{\circ}$ & $79.1 \pm 1.05^{\circ}$ \\
\hline 3 & ANB & $2^{\circ}$ & Steiner ${ }^{6}$ & $2.8 \pm 1.00^{\circ}$ & $2.3 \pm 0.98^{\circ}$ \\
\hline 4 & Beta Angle & $27^{\circ}-35^{\circ}$ & Baik $^{7}$ & $28.5 \pm 2.11^{\circ}$ & $28.5 \pm 2.05^{\circ}$ \\
\hline 5 & Bjork Sum & $396^{\circ}$ & Jarabak $^{8}$ & $394 \pm 1.31^{\circ}$ & $393 \pm 1.5^{\circ}$ \\
\hline 6 & SN-Palatal Plane & $7^{\circ} \pm 3^{\circ}$ & Bell, Proffit \& White ${ }^{8}$ & $8.55 \pm 1.31^{\circ}$ & $8.32 \pm 1.51^{\circ}$ \\
\hline 7 & SN-GoGn & $32^{\circ} \pm 2^{\circ}$ & Steiner ${ }^{6}$ & $33.05 \pm 1.23^{\circ}$ & $32.64 \pm 1.02^{\circ}$ \\
\hline 8 & Inter-incisal Angle & $131^{\circ}$ & Steiner ${ }^{6}$ & $128.65 \pm 1.49^{\circ}$ & $129.12 \pm 0.69^{\circ}$ \\
\hline 9 & Upper incisor to NA (Angular) & $22^{\circ}$ & Steiner ${ }^{6}$ & $23.6 \pm 0.94^{\circ}$ & $23.05 \pm 0.02^{\circ}$ \\
\hline 10 & Upper incisor to NA (Linear) & $4 \mathrm{~mm}$ & Steiner ${ }^{6}$ & $5.85 \pm 0.67 \mathrm{~mm}$ & $5.36 \pm 0.05$ \\
\hline 11 & Lower incisor to NB (Angular) & $25^{\circ}$ & Steiner ${ }^{6}$ & $26.35 \pm 0.74^{\circ}$ & $26.83 \pm 0.31^{\circ}$ \\
\hline 12 & Lower incisor to NB (Linear) & $4 \mathrm{~mm}$ & Steiner ${ }^{6}$ & $6 \pm 1.16 \mathrm{~mm}$ & $5.89 \pm 1.31 \mathrm{~mm}$ \\
\hline 13 & IMPA & $90^{\circ}$ & Tweed ${ }^{9}$ & $91.55 \pm 0.94^{\circ}$ & $90.78 \pm 1.07^{\circ}$ \\
\hline 14 & Upper incisor to SN & $102^{\circ} \pm 2^{\circ}$ & Jarabak $^{8}$ & $104.15 \pm 1.26^{\circ}$ & $105.09 \pm 1.17^{\circ}$ \\
\hline 15 & Nasolabial Angle & $102^{\circ} \pm 8^{\circ}$ & McNamara 9 & $93.85 \pm 7.16^{\circ}$ & $96.85 \pm 4.49^{\circ}$ \\
\hline 16 & Upper lip thickness & $15 \mathrm{~mm}$ & Holdaway ${ }^{10}$ & $13.9 \pm 1.13 \mathrm{~mm}$ & $13.5 \pm 1.91 \mathrm{~mm}$ \\
\hline 17 & Lip strain & $1 \mathrm{~mm}$ & Holdaway ${ }^{10}$ & $1.22 \pm 0.61 \mathrm{~mm}$ & $1.50 \pm 0.04 \mathrm{~mm}$ \\
\hline 18 & H-Angle & $7^{\circ}-15^{\circ}$ & Holdaway ${ }^{10}$ & $12.85 \pm 2.6^{\circ}$ & $13.72 \pm 2.19^{\circ}$ \\
\hline 19 & Lower lip to E-line & $-2 \pm 2 m m$ & Rickett ${ }^{11}$ & $-0.37 \pm 0.9 m$ & $-0.15 \pm 0.5 \mathrm{~m}$ \\
\hline
\end{tabular}




\section{RESULT}

The mean and standard deviation values of all cephalometric parameters of both male and female South Indian subjects are presented in Table 1.

\section{DISCUSSION}

The results of the present study showed that the South Indian subjects possess proclination of anterior teeth as shown by the parameters like upper incisor to NA, lower incisor to NB, interincisal angle, IMPA and upper incisor to SN.

The mean values of naso-labial angle for males $\left(93.85 \pm 7.16^{\circ}\right)$ and females $\left(96.85 \pm 4.49^{\circ}\right)$ showed a huge range of difference due to variation in soft tissues among the subjects. SNA, SNB and ANB were in accordance with Hasund's Analysis. Upper lip thickness and lip strain were also in accordance with Holdaway's Analysis.

The major shortcoming in any study that defines norms is that; it reflects the esthetic bias of the investigator in selecting the sample. It may not necessarily agree with the esthetic perception of the people at large. Even amongst the dental specialties, esthetic preferences are known to differ. Similar to other studies; the present study also suffered the shortcoming of being a two-dimensional study of the three dimensional tissue. With the emerging of cone beam imaging and 3D photography, new levels of facial analysis are expected to be developed in near future.

\section{CONCLUSION}

The finding suggests that different set of cephalometric norms should be employed for different ethnic groups. As mildly proclined incisors and mild facial convexity are considered normal in South Indian scenario; the orthodontists and oral surgeons should use local cephalometric norms as reference for optimizing treatment planning to obtain optimum esthetic outcome.

\section{ACKNOWLEDGEMENT}

Our sincere thanks to faculty and post graduate students, Department of Oral Medicine and Radiology, Kamineni Institute of Dental Sciences for their cooperation during the study.

\section{REFERENCES}

1. Bailey KB. Cephalometric parameters of adults with naturally occurring excellent occlusion. The University at Birmingham, 1998.

2. Kalha AS, Latif A, Govardhan SN. Soft tissue cephalometric norms in South Indian ethnic population. Am J Orthod Dentofacial Orthop 2008; 133:876-81.

3. Almyra M, Naranjilla S, Janson IR. Cephalometric floating norms as a guide toward a harmonious individual craniofacial pattern among Filipinos. Angle Orthod 2009; 79:6:1 162-8.

4. Wei SHY. A roentgenographic cephalometric study of prognathism in Chinese males and females. Angle Orthod 1968; 38:4:305-20.

5. Viazis AD. A Cephalometric analysis based on natural head position. J Clin Orthod 1991; Mar:172-81

6. Steiner CC. Cephalometrics in clinical practice. Angle Orthod 1959; 29:8-29

7. Baik CY. A new approach of assessing sagittal discrepancies: The Beta angle. Am J Orthod 2004; 126:100-5.

8. Ricketts RM. The biologic significance of the divine proportion and Fibonacci series. Am J Orthod 1982; 81:5:351-70

9. Athanasios EA. Orthodontic Cephalometry. 2nd Edition 1997.

10. Alexander Jacobson: Radiographic cephalometry. 1st Edition, Quintessence Publishing 1995.

11. Holdaway RA. A soft tissue cephalometric analysis and its use in orthodontic treatment planning: Part I. Am J Orthod 1983; 85:4:1-28.

12. Raju NS, Prasad KG, Jayade VP. A modified approach for obtaining cephalograms in the natural head position. J Orthod 2001; $28(1): 25-8$.

13. Zylinski CG, Nanda RS, Kapila S. Analysis of soft tissue facial Pprofile in White Mmales. Am J Orthod Dentofacial Orthop 1992; 101:514-8.

14. Sutter Jr RE, Turley PK. Soft tissue evaluation of contemporary Caucasian and African American female facial profiles. Angle Orthod 1998; 68:487-96.

15. Lundstöm A, Lundström F, Lebret LML, Moorrees CFA. Natural head position and natural head orientation: Basic considerations in cephalometric analysis and research. Eur J Orthod 1993; 17:111-2. 